\title{
Paul and the Faithfulness of God \\ A Review Essay (Part 2) \\ Chris Tilling
}

Editor's note: Due to the length of this review essay, it is published in two parts. This is the second.

\section{Critical issue 4: Evil.}

Certainly, Wright cleverly manages to explain just how Paul's understanding of evil changed in light of Jesus Christ, instead of simply claiming that Paul's understanding of "Sin" came about retrospectively. However, despite this, I suggest that Wright has again not sufficiently allowed Paul's letters to dictate the terms. As I have (relatively uncontroversially) detailed elsewhere, ${ }^{1}$ Paul's language relating to "evil" involves two points. First, it is spoken of in

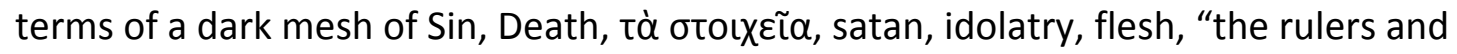
authorities" etc. Second, this language has one thing in common: these matters exercise force and in so doing enslave. This is by far and away the dominant language in Paul, and it speaks of enslavement. However, Wright's 76 page account has a mere two instances of words such as "slave", "enslaves" and "slavery" (744). This is to be contrasted with the number of times Wright uses the word "exile" in these pages: seven times. My worry is that Wright's wider narrative concerns are again trumping the details of Paul's letters. He, indeed, claims the following:

When we map this solution-driven reworking of the 'plight' on to the picture of second-temple Judaism we sketched in chapter 2 above, one thing becomes clear. What is now being offered is the 'solution' to the problem of Israel's 'exile', the ongoing condition from the time of the geographical Babylonian exile to the present. (761)

But here, "evil" seems to be mischaracterised, at least compared to the language Paul uses most often. Sin's problem, for Wright, is not so much that it produces slavery (though he does mention this in passing occasionally) as it is something that "charges" (752 and many other pages) and creates "guilt" (777, 947, 969 and many other pages). Corresponding to

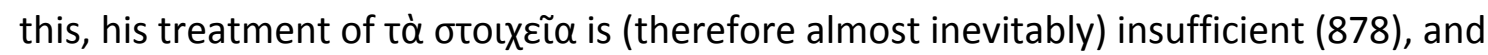
becomes something he considers "puzzling" (1147).

Not surprisingly, this leads to the importation of particularly retributive notions of justice into Paul, even though they are peripheral in the Pauline letters, a matter I will return to in the next critical issue. Note Wright's multiplication of the word "punishment", "guilt",

1. Tilling, C. (2015). "Paul, Evil and Justification Debates," in Keith, C. and Stuckenbruck, L. T. (Eds). Evil in Second Temple Judaism and Early Christianity. Tübingen: Mohr, forthcoming. 
"condemnation" and such like, and how they are used in the same breath as the words "forensic" or "legal" $(777,939,1000)$. This also seems to drive his understanding of the

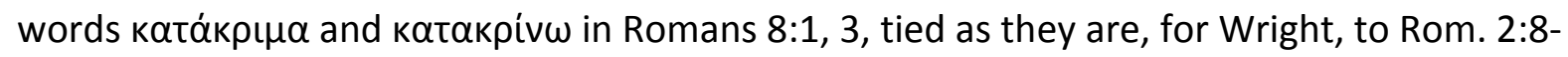

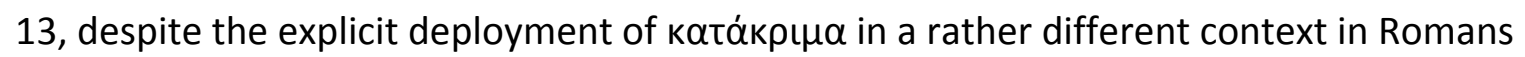
5:16, 18 (thus arguably justifying Campbell's analysis of the hermeneutical role of Romans 1:18-32 in contemporary Pauline scholarship). ${ }^{2}$ Hence Rom. 8:3, for Wright, talks about condemnation as judicial punishment (898-99), and this is precisely what it means to be "forensic" (900).

But all of this is to import notions into Paul, and in so doing put things out of shape. Wright's account of evil co-opts Pauline language into themes peripheral to Paul. I suggest that the very occasional nod in the direction of sin as a "power" implicitly makes my point. For example, Wright reads Romans 5-8 with minimal mention of sin in terms of slavery (which is noteworthy enough). However, he then adds, in a revealing footnote ( 843 n.200), that the language of sin as a power, in $5-8$, should be subsumed into concerns about idolatry and immorality, understood in retributive terms. But this is more of an assertion than a justification, one that allows Wright to move away from the dominant language of Paul's letters. $^{3}$

This is perhaps why one of his most common illustrations for describing sin involves use of the language of "infection" or "disease" (e.g., 754, particularly 770, 899, 1069), rather than as something that enslaves. Evil is further described as "the corruption of the human vocation to rule God's world" (628), which has extremely minimal purchase in Paul's letters. He speaks of the solution to "get the human project back on track", something that drives his understanding of "sin" (795). But again, Paul's letters drive his concerns only tangentially, and therefore-to my mind-unconvincingly.

\section{Critical issue 5: Justification.}

This problematic account of "evil" related language in Paul feeds directly into his account of justification, creating problems for something that is "in a measure... the very heart of our entire topic" (774).

First, mention must be made of his problematic account of "justice". Very often, it seems "forensic", for Wright, means specifically "retributive justice" (903). I don't think Wright has purveyed the various interpretative possibilities and come to the conclusion that

2. Campbell, D. A. (2009). The Deliverance of God: An Apocalyptic Rereading of Justification in Paul. Grand Rapids, Mich.: Eerdmans. For example, see how Romans 1:18ff activates in later parts of his reading of Rom., even 5-8 (888), with the notion of "guilt" imported over.

3. The same thing happens a little later, in exegeting Gal., where he affirms the presence of deliverance from sin, but then effectively asserts "yes, but the point of the passage is as I have construed it". He then adds, "Paul presupposes (and occasionally refers to) the former in order here to expound the latter" (969 n.542), but the "occasionally" in this sentence is misplaced, and I see no reason to believe his claim that it is used to "expound" his own wider approach. 
"retributive" and "restorative" justice is what we find in Paul. Instead, there are clues that Wright is simply unaware of other possibilities.

Rather tellingly, he writes the following about the language of "put to rights":

The reason I retain the English usage is because 'putting something to rights' carries not only the meaning of sorting it out, making it work properly, putting right what was wrong with it, but also the notion of justice. Despite the dangers of our late-modern 'rights culture', always threatening to collapse into the mere swapping of thwarted prejudices, the idea of restoring someone's proper 'rights', and doing so on a cosmic scale, is endemic to the biblical notion of justice. (1085 n.186)

"The" biblical notion of justice? It seems Wright works with at least a couple: retributive as well as restorative notions. What a "rights" culture has to do with this, I am also not sure. "Justice" (and related terms) is-and has always been-one of the most hotly debated terms in political philosophy, deeply intertwined, as it is, with complementary accounts of rationality and the good life. ${ }^{4}$ Michael Sandel's primer on justice has nine distinguishable meanings. ${ }^{5}$ So anyone making the kind of monochromatic semantic assertions I see in Wright is really just placarding their own unfamiliarity with these crucial matters. Hence, when Wright speaks of ultimate vindication "in the legal, forensic sense" (936), I must ask: which "legal" sense?

I suspect that this is why Wright resorted to the language of "paradox" on page 933. There, he speaks about "the problem" in terms of guilt a couple of times, and this in the context of God being "impartial". This is why it becomes, for Wright, a "paradox" that God justifies the ungodly (Rom. 4:5. See Wright's discussion in 947-948). But perhaps this is only a "paradox" because of Wright's imported notions of "justice", rather than because of the way Paul uses the language. ${ }^{6}$

Second, Wright does not seem fully to appreciate the import of speech-act theory (although he does at least mention it) for Paul's use of $\delta$ เк-words. Wright would have been advised to have included it more thoroughly into his reasoning on at least p. 797. Arguably, in the

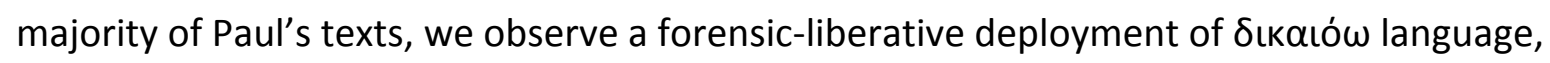
which is to say that it is a verbal declaration that is performative in nature, and thus effects a result: deliverance or liberation. ${ }^{7}$ This corresponds with the dominant concern in Paul's

4. MacIntyre, A. (1988). Whose Justice? Which Rationality? Notre Dame, Ind.: University of Notre Dame Press. 5. Sandel, M. J. (2007). Justice: A Reader. Oxford: Oxford University Press.

6. And I cannot imagine that Wright's rhetoric of "paradox" will impress the likes of Heikki Räisänen.

7. A judge's pronouncement makes things happen: either to go to jail, or to be "set free". On this, see Campbell, D. A. (2009). The Deliverance of God: An Apocalyptic Rereading of Justification in Paul. Grand Rapids,

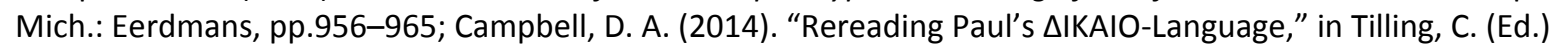
Beyond Old and New Perspectives on Paul. Eugene, Or.: Cascade, pp.196-213. 
language relating to evil that enslaves, as well as that involving justification in the context of being "set free". 8

Instead, as noted in the previous section, due to Wright's "controlling story" he is in danger of sucking different notions of justice into Paul, and the associated matters of "guilt", "punishment" and such like. Corresponding to this, he speaks of the solution to evil not as deliverance but as the need to be "forgiven" $(847,860,886,915,949)$, to be part of the sinforgiven family $(931,964,1031)$, or a member of "forgiven-humans" $(943,1029)$, etc. Indeed, not only does Wright regularly use the word "forgiveness" (949), it becomes central to his account of justification. So "the verdict dikaios" is synonymous with "'righteous', 'forgiven', 'covenant member', which is issued, as Paul says, 'upon that faith' (Philippians 3:9)" (955). Again: "Justification' is the declaration of the one God, on the basis of the death of Jesus: this really is my adopted child, a member of Abraham's covenant family, whose sins are forgiven." (958-959, italics mine). ${ }^{9}$ The justified person "is 'in the right', ... their sins are forgiven" (959). The following is most revealing:

"The justification of the ungodly, by the fresh act of divine grace, is not only the divine means of forgiving sinners. It is also, for the same reason and as part of the same act, the divine means of creating the single Abraham-family. Indeed, it is because of the forensic verdict that the covenantal declaration can take place: the one God 'justifies the ungodly', bringing them into the one family" (961, italics mine).

Justification is more than just forensic for Wright, but when it is forensic, it implies forgiveness. This happens arguably because "legal" concerns, for Wright, imply "guilt", "condemnation" and such like, which are associated with retributive notions of justice. But the crucial issue is that almost none of this language is dominant in Paul (consider, for example, how infrequently Paul speaks of "forgiveness" and "guilt").

This is my claim: once again, what is dominant in Paul becomes peripheral in Wright's account, and what is at best peripheral in Paul becomes central for Wright. ${ }^{10}$

\section{Critical issue 6: Paul's aims.}

8. On all of this, see my forthcoming article, Tilling, C. (2015). "Paul, Evil and Justification Debates," in Keith, C. and Stuckenbruck, L. T. (Eds). Evil in Second Temple Judaism and Early Christianity. Tübingen: Mohr, forthcoming.

9. I found it strange that Wright says the following: "On 'adoption' see now the important study of Burke" (950 n.489, referring to Burke, T. J. (2006). Adopted Into God's Family: Exploring a Pauline Metaphor, New Studies in Biblical Theology. Downers Grove, III.: IVP.). This is odd because many of Burke's key arguments seem to contradict Wright's own position on important issues relating to "adoption" language.

10. A word on his exegesis of Gal. 3 in this section of $P F G$, must be offered. I remain mostly unconvinced by his argument which seeks to qualifying Paul's language about Abraham's single offspring as "Christ" (in 3:16). He states, for example, that "the 'seed' has apparently been narrowed down in verse 16 to one person" (869, italics mine), when in fact this narrowing down is explicit. Neither am I persuaded that he adequately accounts for the fact that the promise is the Spirit in 3:14 (see 972), nor the relation of this verse to 3:2-5. 
One of the strengths of Wright's project is that he attempts to answer a lot of questions all at once. Hence, driven by his "worldview" analysis, he needs also to ask about the aims of Paul (cf. 1046). Although Wright details so much that others have treated too quickly, I argue that he also misses something of vital importance, despite the fact he could have discussed it in Part II, or chapters 11 and 16. What he does not express is what Paul himself explicitly states to be one of his most existential urgent goals: the presence of Christ. ${ }^{11}$ So Paul, in Phil. 1:20-23, speaks of his "desire is to depart and be with Christ, for that is far better". Or again, Paul states that "we would rather be ... at home with the Lord" (2 Cor. 5:1), and expresses his great goal, namely "we will be with the Lord forever" (1 Thess. 4:17), which becomes the basis for "encouraging one another" (4:18. Cf. also 5:10-11). None of this, however, is discussed, or even mentioned in terms of Paul's goals (or anywhere in PFG as far as I can see). Likewise, the longing Paul speaks of, which resonates with language found in the Psalms, such as 63; 84:1-2 etc., is not included in Wright's account in this regard.

This may correspond to the way Wright tends to instrumentalise the identity of Jesus (and the Spirit) such that the affirmation of their "divinity" is not "for its own sake" but in order to say that "the one God had established his kingdom" (733, italics suppressed). For this reason, Wright asserts that Paul's monotheism is not about "bare belief" (a sentiment with which I entirely agree), but rather "an agenda" (734). But speaking of monotheism as an agenda (which I can partly affirm), dissolves Paul's more lively, relational and love-orientated language in a rather pragmatic and less personal direction. ${ }^{12}$

So I am left wondering why Wright has missed this crucial Pauline language about goals and aims. Two reasons suggest themselves, which "dovetail" with much of what we have already seen. First, Wright's own "worldview model", which emphasises a certain construal of Israel's story, involves a polemic against modern understandings of "religious experience" (cf. 971). This is true to an extent, but this then leads Wright to underplay (971-72) the significance of the experience of the Spirit in Gal. 3:1-5 in favour of those narrative concerns, and I am not persuaded that this is justified by suggesting that those who do otherwise merely import a modern view of "religious experience" (971) into the text. This converts to the claim that the "we" of 3:14b refers "to Jews", which sits uncomfortably next to 3:1-5.13 In other words, potential exegetical problems that detract from the text once again surface as a result of Wright's interpretative grid.

Second, in discussing the plots and sub-plots in Paul's "storied worldview" Wright arguably does not pay sufficient attention to the "story of the church" (as he explicitly states, and attempts to justify, on 536). But precisely this "story", if that's how one should speak of it, would have sharpened his sight to see so much in Paul's letters that he misses.

11. See the discussion in Tilling, C. (2012). Paul's Divine Christology. WUNT II. Tübingen: Mohr Siebeck, pp.106-113, and other Pauline language set out my $6^{\text {th }}$ chapter.

12. On all of this, see Tilling, C. Paul's Divine Christology, chapters 4-5.

13. See also 1 Cor. 2:3-5, as well as the notes in de Boer, M. C. (2011). Galatians: A Commentary. The New Testament Library. Louisville, Ky.: Westminster John Knox Press, pp.183-184. 
Perhaps this is also why he thinks matters relating to the salvation of the individual, and the need of that individual to know that he or she is "forgiven", are "certainly not Paul's primary concern" (850). I can agree with this to an extent, but I have questions about Wright's polemic against individualism. First, I prefer to speak of the "interpersonal" or "relational" nature of Paul's communities, which avoids the undoubted problem of "individualism" as well as language which tends to speak of a communal mass which absorbs the importance of individuals and their experiences. Second, let us not forget the significance of Paul's

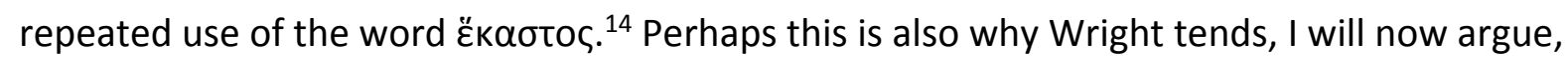
to underplay the historical particularity and contingency of local ecclesial communities.

\section{Critical issue 7: Contingency.}

Although Wright aims to present a "thick description" of Paul (25, 29 etc.), I am not persuaded that he entirely succeeds in this project. Undoubtedly he does to a good extent, and certainly as it relates to aspects of Paul's hermeneutics as a reader of texts. But the historical particularity of the Pauline communities seems to be underplayed. For example, one could question whether his account of the problem of the Torah, for the Galatians, sufficiently takes into account the role and nature of Paul's opponents (see, e.g., 508, 52628 ), who were troubling the churches of Galatia. Indeed, I doubt whether his engagement with the crucial question of the identity of Paul's opponents more broadly is adequate (548 n.42). ${ }^{15}$

Further, Wright is less comfortable when it comes to matters of chronology, and the historical particularity that is associated with this, as is seen in his lack of knowledge or use of key monographs relating to this issue, such as those penned by Jewett, Knox, Riesner, etc. ${ }^{16}$ The latter's absence, particularly his monograph Paul's Early Period, was felt strongly when Wright discussed Paul's missionary geographical plans and motives (1500), to which Riesner devotes approximately 100 pages. ${ }^{17}$ I thus remain unpersuaded that Wright presents a "thick historical description of [Paul's] social and cultural context, and the positioning of his communities within that context" (1038).

Naturally, this has wider ramifications. For example, when Wright details how justification language supposedly chronologically developed (965), his argument seem to become a little

14. See, e.g., Fitzmyer, J. A. (2008). First Corinthians, Anchor Bible. London: Yale University Press, p.307; the insightful comments in Samra, J. G. (2006). Being Conformed to Christ in Community: A Study of Maturity, Maturation and the Local Church in the Undisputed Pauline Epistles. London: T\&T Clark, pp.28-32; as well as the nuanced work of Burnett, G. W. (2001). Paul and the Salvation of the Individual. Köln: Brill.

15. On all of this, Wright's rhetorical "whipping boy", Lou Martyn, offers more by way of a "historically thick" description of Paul's historical particularity than Wright (see Martyn, J. L. (1997). Galatians: A New Translation with Introduction and Commentary, Anchor Bible. London: Doubleday).

16. Jewett, R. (1979). Dating Paul's Life. London: SCM Press; Knox, J. (1950). Chapters in a Life of Paul. Nashville: Abingdon.

17. Riesner, R. (1998). Paul's Early Period: Chronology, Mission Strategy, Theology. Carlisle: Paternoster, pp.229-317. 
knotted, if not contradictory. He first asserts that forensic meanings are explored in Romans, but that in Galatians and Philippians justification language is "almost entirely [to be understood] in terms of 'covenant"' (965). But a little later, Wright claims that both forensic and participationist modes of thought are present in Galatians (974).

I suspect that Wright acknowledges this lack of sensitivity to the immediate concerns of the Pauline communities when he is compelled to offer an all too brief (and I think unsatisfactory) justification for his focus on the wider "story of Israel" on page 1015. When countenancing the charge that story might seem "remote and scarcely interesting to Gentile Christians in Rome", he asserts:

I sometimes wonder whether such imagined incomprehending listeners are really the coded presence of modern western scholars and preachers who are hoping that Paul will, in his every sentence, say something readily accessible to the deeply non-Jewish concerns of our own day. But what is of most concern to Paul, speaking as he says 'to those who know the law' $(7: 1)$, is to tell the story of Israel because it is the story of the world's redemption.

He continues, claiming that Paul regularly articulates "a narrative which far outstrips any small-scale concerns of this or that group" (1015). But it is not implausible to counter-assert that all of this is said because Wright has not sufficiently articulated what those "small-scale concerns" actually are. ${ }^{18}$ This is arguably one reason why Wright critiques Martyn for his supposed anti-Judaism, at one point. He does this by suggesting that Paul's opponents are defined, by Martyn, as "offering a form of Judaism" (808 n. 109), hence Martyn's Paul is antiJewish. But Martyn's construction of the opponents means that his Paul's problem is certainly not just that they "offer a form of Judaism". The insight is in the historically particular details, something Martyn attends to admirably in his commentary, ${ }^{19}$ where he pieces together precisely what these opponents were saying, on what basis, and why it was a problem for Paul. In other words, Wright's criticism betrays a lack of comprehension of the issues involving historical contingency, and this, in turn, points us towards problems with Wright's rhetoric, which we will now address.

\footnotetext{
18. On all of this, see now the work of one of Wright's key nemeses, Campbell, namely Campbell, D. A. (2014). Framing Paul. Grand Rapids: Eerdmans.

19. Martyn, J. L. (1997). Galatians: A New Translation with Introduction and Commentary, Anchor Bible. London: Doubleday.
} 


\section{Critical issue 8: Caricature, misrepresentation, assertions, uncharitable rhetoric, etc.}

I will first note Wright's misrepresentations and caricatures. Wright's misunderstanding of Bultmann may be less controversial, but I would argue at least the following. To say that Bultmann is an anti-Jewish Heideggerian (1477) is based on an extremely unsympathetic reading, one which does not well represent the "hermeneutic of love" espoused in Wright's first volume in the Christian Origins series, ${ }^{20}$ and one which suggests that Wright is not too familiar with Bultmann's writings. Wright claims that the "shape of the narrative proposed by Bultmann for the New Testament is the same as that of gnosticism" (458), but though "Bultmann frequently and thoroughly examines this correspondence between the Christian narrative and the gnostic narrative, he does so in order to demonstrate the way the Christian narrative constitutes a rejection and critique of gnosticism". ${ }^{21}$ Contra Wright (624), Bultmann does not confine theology to anthropology (a common misunderstanding based on an atomistic reading of Bultmann's Theology of the New Testament). "Bultmann does not think talk about humanity can replace talk about God. He instead argues that we can only talk about God on the basis of revelation, that is, in light of what God actually does. And God's action is saving action".

Wright's regular anti-"apocalyptic reading" invective is one of the least pleasant aspects of PFG, especially given that his criticisms are often misguided. ${ }^{22}$ Let it be said that it is emphatically not the case that the "revelation", which "apocalyptic" readers talk about, must be "essentially non-Jewish" (781). Nor is it the case that their reading is "anti-Jewish" (460-461, 1481), that it involves "sweeping everything else off the table" (see 1218, 1262, 1309 etc), that it ignores the "historical back story of Israel" (902), or that this approach to Paul concerns the arrival of the new "unattached to anything that has preceded it" (1512) with a correlating "rejection of history". Certainly some in the "apocalyptic camp" open themselves up to this kind of critique, but not others. For example, Campbell, a fervent "apocalyptic" reader, writes that those like him "are quite happy to affirm a salvationhistorical dimension within Paul's theology at some point, and are in fact (I would argue) necessarily committed to this." 23 To cite Wright back at himself, "the extreme behaviour of some should not scare us off proper investigation. Just because one daughter elopes with an unsuitable partner, one does not for that reason send all the others to a nunnery." (456) Nor is this reading of Paul a "fad" (902), certainly no more than Wright's approach. Nor is it the case that "apocalyptic" paradigms do not want "a positive reading of Abraham", or claim that there is "no sense of 'continuity' with Abraham at all" (see 781, 784, 971 n.548, 974 n.556., 990). At the very least, Wright seems to confuse an epistemological point with an

20. Wright, N. T. (1992). The New Testament and the People of God: Christian Origins and the Question of God: Part I. London: SPCK, p.64.

21. The text in quotation marks here and in the following is written by Bultmann specialist, Dr. David Congdon, as part of my correspondence with him in December, 2014.

22. I began making a list of references until it got too long: (40-41, 141, 183, 370, 408, 460-61, 467, 475, 484, $499,612,781,783$ n.23 etc.)

23. Campbell, D. A. (2005). The Quest for Paul's Gospel: A Suggested Strategy. London: T\&T Clark, p.67, italics suppressed. 
historical one. This suggests to me that Wright has not fully understood some of the claims developed in the commentaries of Martyn and de Boer.

It is therefore no surprise that Wright does not understand Douglas Campbell's proposals. See, for example, his misunderstandings on 757-758, which ignore the kinds of distinctions Campbell presses. Campbell does not claim that "Paul did not mean what he said" (765), and one could argue that it is Wright's reading that makes Paul not mean what is said. Indeed there is little evidence that Campbell's work has been digested, as it would (or at least should) have altered some of Wright's claims about justification in terms of speech-act theory (as noted above). Most astonishingly, Wright claims that Campbell argues Romans 58 is free from "juristic" language, which he follows with the charge that this kind of thing is "disastrous both exegetically and theologically" (1011. See also 1031). When one makes these kinds of claims, it is better to be sure they are accurate. And they are not. Wright fails to see that Campbell's account is indeed "forensic." Campbell maintains, in contrast to this caricature, that the justice involved is not specifically retributive (so I loop back to my comments about Wright's account of "justification" above).

There are misinterpretations of Barth as well $(200,1388$, where he misses Barth's point about the "subject-matter" and the nature of time, ${ }^{24} 1479$, etc.), which leads to the claim that a Barthian position makes "human response ... hardly necessary" (953), which is highly misleading. ${ }^{25}$ This is then tied to Martyn and de Boer, now charged with making explicit faith in Christ "irrelevant". Due to their focus on the objectivity of justification, it leads them, Wright claims, into "carelessness about actual faith" (954 n.507; 954 n.507, 963. See also 1131). They could respond, I think with Paul on their side, that this objectivity grounds faith and makes it possible.

There is a further lack of consistency in his grasp of "apocalyptic" concerns when he says that its strong point is to say that "Paul sees everything in a new light because the new world has come into existence" (1100). Precisely. Everything! And yet, he says in relation to Romans 1:20-25, that "Paul here assumes [that] the human mind can in principle grasp the truth about the creator God" (1122)... All of this means, sadly, that his explanation for the rise of "apocalyptic", in the final chapter, cannot be taken seriously either (1485-1486). The combined interpretative mistakes are made all the more unfortunate by the number of times Wright repeats such things.

24. On the question of "time" in Barth's commentary, see Harink, D. (2010). "Time and Politics in Four Commentaries on Romans," in Paul, Philosophy, and the Theopolitical Vision: Critical Engagements with Agamben, Badiou, Žižek and Others, Theopolitical Vision. Eugene, Oregon: Cascade, pp.282-312.

25. Barth addresses these issues in the Church Dogmatics in various places and in Barth, K. (1960). The Humanity of God. Richmond: John Knox Press. See also, e.g., Couenhoven, J. (2010). "Karl Barth's Conception(s) of Human and Divine Freedom(s)," in Migliore, D. L. (Ed.) Commanding Grace: Studies in Karl Barth's Ethics. Grand Rapids. Mich.: Eerdmans; Nimmo, P. T. (2007) Being in Action: The Theological Shape of Barth's Ethical Vision. London: T \& T Clark, pp.110-135; Hunsinger, G. (1991). How to Read Karl Barth: The Shape of His Theology. New York: Oxford University Press, chapter 7. 
Arguably, Wright also misunderstands the project of Sachkritik. He suggests that they are claiming "to know better than Paul did what he 'really' intended to say" (467). Apart from the contentious nature of this claim (Sachkritik is really about asking what makes Christianity essentially Christian), one must ask if Wright himself doesn't do something similar. So he charges Paul of "overcompression" in his argument (643), but is this not perhaps simply because Paul has not said everything Wright thinks he intended to say? Later, he asserts that "Paul does not here join those particular dots" (656-7), when speaking of his own account of the Jewish backstory. But again, is that arguably because they were not in Paul's mind to begin with? "As usual", Wright states on page 513, "Paul does not say all that is in his mind at any one time". Wright runs with something pretty close to "mind reading" of Paul, over and above what Paul actually says, in many places (see, e.g., his exegesis of Rom. 10:6 on p.705, and much of Rom. 5-8).

It is necessary to say something about Wright's "assertions" (rather than close argumentation), but it would be tedious to list times I would argue that this can be observed in PFG. I offer some examples in the footnote. ${ }^{26}$

This leads me to note other occasions involving Wright's uncharitable rhetoric. He is not shy to call another scholar's views "puzzling nonsense" (802 n. 92, 934, for example). Even the view of one of his exegetical compadres, Mike Bird, is called "bizarre" (934), and Susan Eastman apparently suggests something one can only call "absurd" (967 n.534). W. S. Campbell and Harink both offer "bizarre charges" (985 n.593), and Mark Nanos "seems to have no idea of what the thrust of Paul's gospel actually was" (1439). His response to Pedersen is, at times, rude (even if I am sympathetic with the substance of a few of Wright's points). He speaks of Pedersen's "breathtaking subjectivism" (1394), and implies that he randomly "seizes upon" evidence, presumably with little reasoning (1398). There is a rude footnote on p.168 (n.367), and he implies that Pedersen is confused and deceptive (1388. See also Wright's "sharp intake of breath" on 1397). ${ }^{27}$ To be honest, I quite enjoy the cut and thrust of such language, but it won't be to everyone's taste.

More seriously, however, I should note the following. Wright's rhetoric against the "apocalyptic" reading gets bolder the longer one reads into PFG, to a point where Wright is reckless enough to associate apocalyptic readings with the Nazis (1476-77 and n.8), stating not only that, although these readers are apparently ideologically opposed to historical progression, they are, he exclaims, "now rather proud of [their] three-generational lineage" (1477). Some of this indeed comes close to ad hominem. Wright's constant recourse to the

\footnotetext{
26. Again, I began making a list but it would have become too long. But for starters see, e.g., the claim that "good theology is always rooted in good history" (87). Or his claim that "[m]any commentators simply assume that the biblical context of the passage Paul is using is irrelevant" (677). "Simply assume", or "do not think it is persuasive"? A few more: 480 (and claims about "the kingdom"), 659 (that Roman 6-8 constitutes "a massive retelling of the Exodus-narrative") , 716 (and the Exodus-narrative again), 942 (and the supposed "underlying theme of Romans 1-8"), etc.

27. I am grateful to Jeremiah Bailey for highlighting some of these references for me.
} 
charge of supersessionism against the "apocalyptic" reading (e.g., 807), must also be seen as mostly unimpressive and uncharitable rhetoric.

Finally, there are numerous occasions when Wright commits the "middle argument fallacy" in ways which also set up false options (e.g., 466, 987, 1038, 1272f). In many respects, his frequent language of Paul being "essentially Jewish" can be categorised in this light, as it is used to pigeonhole other readings that hesitate to accept his account of, and role played by, the "story of Israel." He also seems to critique Avemaria for "allowing the big picture to trump the tell-tale details" (937 n.460), which is rather ironic, for as I have argued above, I would contend that this is often precisely what Wright does.

\section{Why has this happened and what is required?}

Much of what Wright says is very close to everything I would want to affirm about Paul. But it is often "close in the way that two paths might be close, and even parallel, though separated by a high wall or a narrow but fast-flowing river" (1480). Despite its brilliance, I have suggested that PFG has a number of potential flaws. In the third part of this review essay, I finish by asking what can explain these problems? In so doing, I draw many of my arguments together.

I have already mentioned a number of issues above, namely Wright's sidelining of the interpersonal "story" of Christ and the church, the nature of the "controlling story", the way the Pauline text is not given sufficient space to shape that "story", and the lack of attention to many historically contingent matters. A couple more need to be noted.

First, "intertextual maximalism." ${ }^{28}$ Even one word can pull through an entire allusion (see, e.g., 13). But this is controversial (see, e.g., 1010, 1345), and tends to happen only on Wright's terms. Hence, for example, the binding of Isaac is muted (697), even though the story is explicitly cited in Romans 8 . His confidence sometimes gets the better of him, too. So "Paul [in Gal. 4:1-11] is now talking about the Exodus" (876), which is, of course, factually false. It may be alluded to, but that is something else. If a Pauline allusion hints at language which could overlap with an Exodus theme, or some other matter related to Wright's controlling story, it is inevitably used to pull through that wider story into Paul, sometimes whether it is entirely appropriate or not. For example, when Paul speaks of God "sending the son", for Wright this implies a wisdom Christology (671), but I suggest that this is a good example of overcooking the evidence. ${ }^{29}$ Any proposal that treats Paul's language as essentially synecdochic needs to be vigourously tested against Paul's letters for correction. Wright, as I argued above, has not always done this in a way that convinces.

28. Campbell, D. A. "Review of N. T. (Tom) Wright's Paul and the Faithfulness of God," SJT (forthcoming 2015). 29. For the record, intertextuality must be factored in, but it need not be done on Wright's terms. 
Second, the broad brushstrokes exegetical procedure. His recourse to "poetic sequence," otherwise called Paul's "sequence of thought" (609), or "flow of thought" (813), arguably leads Wright to what can be called "verse jumping" (see, e.g., 836-837, or when he reads Rom 5-8). A word here, and a word there, and like stepping stones over a river we land on the other side (of the controlling story, of course). However, more than a few texts are thereby marginalised or ignored. Moreover, this tends not always to lead us to the heart of Paul's letters, but to the heart of Wright's over-arching vision. This technique is then justified, when it starts to look suspicious in exegetical practice, in a not altogether satisfying manner (see, e.g., 870 n.271), which is to say that Wright simply asserts an argument via comparison with a tangentially relevant issue. ${ }^{30}$

This is all to argue, in tandem with my earlier arguments, that the errors I claim are in PFG can mostly be traced back to Wright's (sometimes problematic) "controlling story", which is then pulled into Paul, sometimes rather heavy-handedly, via Wright's "intertextual maximalism", and then justified by his "sequence of thought" exegesis, all of which is not restrained by the historical particularity of Paul's communities and their needs, particularly as it is shaped by interpersonal Christ-church matters.

It follows naturally to then ask whether Wright, too, ends up finding a Paul in his own image (a problem he witnesses in others, xix). We have ended up with a complex, multifaceted yet broadly coherent Paul in PFG, and yet what stands out to me is the way Wright's Paul is a scholar of texts. In this way Wright's Paul continually "outflanks" others $(1265,1509,1511)$, which is precisely what Wright proposes he does (614 n.17). Of course, Wright's project cannot be dismissed on these terms, or any other, but I question his confidence to be able to put Paul back together again "on his own terms." 31

What is needed? Only a few scholars have ever had Wright's learning or brilliance, something most of us cannot pretend to imitate. At the very least he models an energy and determination to find Paul that the wider scholarly community should attempt to replicate. Plus, his "thick description" is a step in the right direction, towards concern for Paul's full historical locatedness. Finally, Wright is very transparent about the nature of his approach, the models he uses and the scope of questions he seeks to address. He paves a way forward, showing a path which would seek to resist presenting a lopsided Paul driven by undisclosed interpretative agendas. I would urge that Paul's texts be kept centre stage, allowed full right of reply to all over-arching stories and reading paradigms, in as much as that is possible, of

\footnotetext{
30. This is not to say that one should focus on isolated sayings instead of whole passages (which he thinks his critics charge of doing, 965).

31. In rather positivist terms, Wright suggests that we "put Paul's argument back together on its own terms" (869). There is a correlating tendency towards historicising, here. So he implies that one is (and therefore can) to "think historically rather than ideologically" (397, italics mine). See also claims made on p.428, and the language of "genuinely historical investigation" (1357) and "genuinely historical exegesis" (1478). What makes historical work "genuine" for Wright, I wonder? Surely it would not be ideology-proof.
} 
course. ${ }^{32}$ Arguably, this calls for a relational (and therefore revelational) approach, ${ }^{33}$ which operates with a christologically weighted oscillation between Paul's text and framing matters (including that of "backstory" / "backstories"). Hence, and most of all, it will require attendance to Christ, the "vital key" (826). As also for Wright, precisely when Paul speaks of Jesus the Messiah, right there we see that the "events of Jesus's death and resurrection compelled Paul" and "caused him to read old texts in new ways" (827). And not only texts, but also all relationships and indeed everything else is seen quite differently in the light of Christ (2 Cor. 5:16-17, Phil. 3:8). Wright's monumental PFG, though not without its problems, has lead us a good way down this path.

Dr Chris Tilling is Senior Lecturer in New Testament at St Mellitus College and St Paul's Theological Centre and Visiting Lecturer in Theology at King's College, London. He blogs at http://blog.christilling.de

32. Wright is aware of this need (xviii, 1359), of course, but I am not persuaded that he follows through, as I have argued.

33. See Tilling, C. (2014). “Campbell's Apocalyptic Gospel and Pauline Athanasianism,” in Tilling, C. (Ed.) Beyond Old and New Perspectives on Paul: Reflections on the Work of Douglas Campbell. Eugene, Or.: Cascade, pp.68-73, for more on this. 